\title{
Comparative Study between Intramuscular and Intra-Arterial Autologous Transplantation of Bone Marrow Derived Mononuclear Cells in Treatment of Non Reconstructable Critical Limb Ischemia
}

\author{
HESHAM M.I. EL-ASHRY, M.Sc.*; HASSAN A.H. ALI, M.D.**; SAIED M.H. ABDOU, M.D.*** and \\ AHMED M.I. TAWFIK, M.D.** \\ The Departments of General Surgery*, Vascular Surgery** and Clinical Pathology***, Faculty of Medicine, Tanta University
}

\begin{abstract}
Background: Critical limb ischemia is a limb threatening condition characterized by ischemic rest pain, non-healing wounds, or tissue gangrene related to the peripheral arteria occlusive disease. Treatment of non-reconstructable critical limb ischemia is a challenge despite advances in surgical and endovascular techniques.

Aim: The aim is to compare the efficacy and safety of intramuscular and intra-arterial autologous transplantation of bone marrow derived mononuclear cells in treatment of nonreconstructable critical limb ischemia.

Material and Methods: This study was conducted on forty-five patients with non-reconstructable critical limb ischemia stages III or IV (Fontaine's classification) with ABI below 0.5 and the arteriogram showed no distal run-off and no option for revascularization. All patients were subjected to the best medical treatment according to (TASC II) then randomized (closed envelop) into three equal groups (15 patients in each group). Group I, II: Subjected to intra-arterial and intra-muscular autologous transplantation of bone marrow derived cells respectively while Group III only subjected to the best medical treatment as a control group. The primary outcomes were amputation free-survival and absence of therapy related major complication while secondary outcomes were improvement of ischemic rest pain assessed by Visual Analogue Scale (VAS), improvement of ischemic tissue perfusion assessed by Ankle Brachial Index (ABI), improvement of pain free walking distance, improvement of ischemic wound healing, detection of new collaterals in the angiogram and presence of neo-angiogenesis in calf muscle tru-cut needle biopsy.

Results: There were no significant differences between both Group I, II as regards the primary outcomes (limb salvage rates were $81.8 \%, 72.7 \%$ respectively, without therapy related major complication or mortality) and secondary outcomes during the follow-up period. When compared with the control group there were significant differences in both primary (limb salvage rate was $27.7 \%$ ) and secondary outcomes.
\end{abstract}

Correspondence to: Dr. Hesham M.I. El-Ashry, E-Mail: dr.hesham.m.elashry@gmail.com
Conclusions: No difference between autologous transplantation of bone marrow derived mononuclear cells either by intra-arterial or intra-muscular administration. Both routes are simple, safe and effective.

Key Words: Non-reconstructable - Critical limb ischemia Bone marrow stem cells - Autologous transplantation.

\section{Introduction}

CRITICAL Limb Ischemia (CLI) is the advanced form of the Peripheral Arterial occlusive Disease (PAD) characterized by a chronic ischemic rest pain ( $>2$ weeks), ischemic ulcers, nonhealing wounds, or tissue gangrene and a serious decrease in the tissue perfusion with a potential threat to limb viability and a significant risk of limb loss [1].

The prognosis of patients with Critical Limb Ischemia (CLI) is poor as regarding survival and limb salvage despite advanced therapeutic options such as surgical and endovascular interventions [2].

About $20-30 \%$ of CLI patients are not eligible for distal arterial revascularization because of concomitant disease or occlusion of crural and pedal vessels with absent patent distal arterial bed for a successful revascularization [3] .

The therapeutic options for patients with previous failed revascularization procedures or in patients with non-reconstructable critical limb ischemia are very limited. High percentage of $40 \%$ of these patients will require amputation within 6 months with significant post-operative morbidity, physical disability, emotional and financial impact and a poor quality of life [4] 
Autologous transplantation of bone marrow derived progenitor cells has been identified as a potential therapeutic option to induce therapeutic angiogenesis [5] . Clinical benefits were reported including improvement of Ankle-Brachial Index $(\mathrm{ABI})$, promoting ischemic wound healing reduction of rest pain, increasing the pain free walking distance and preventing amputation [6]

\section{Aim of the study:}

The aim of the study is to compare the efficacy and safety of intra-arterial and intramuscular autologous transplantation of bone marrow derived mononuclear cells in treatment of non-reconstructable critical lower limb ischemia.

\section{Patients and Methods}

This study included 45 patients with nonreconstructable critical lower limb ischemia stages III or IV (Fontaine's classification) with no distal run-off after failed or impossible revascularization. All patients were admitted to the Vascular Surgery Unit, Tanta University Hospital, Tanta, Egypt in the period from December 2015 till December 2016. All patients subjected to the best medical treatment according to (TASC II) and randomly divided (closed envelop) into three groups (each included 15 patients) according to the route of mononuclear cells administration either intraarterial catheter directed or direct intra-muscular injection and the third group as a control group.

The study was approved by the Ethical Committee of the Faculty of Medicine, Tanta University (approval code: 30639/12/15). A written informed consent was taken. The procedure was explained in details and in a clear simple language. All possible therapy related complications were explained with emphasis that the patients can withdraw from the study at any stage if they wish.

All patients were subjected to complete history taking including the risk factors (smoking, diabetes, hypertension, hyperlipidemia) and associated comorbidities (cardiac or cerebrovascular diseases). Detailed physical examination was conducted, including the pulse state in the affected limb, presence of tissue loss or gangrene, evaluation of the microcirculation (temperature, capillary refill time and oxygen saturation using the pulse oxymetry), measurement of Ankle-Brachial Index (ABI), the pain free walking distance and the severity of rest pain according to VAS. Duplex study and CT angiography were also done for all patients to detect the severity and the extent of the arterial occlusion.

\section{Inclusion and exclusion criteria:}

Patients with chronic critical lower limb ischemia stage III or IV (Fontaine's classification) and with ABI below 0.5 were included. Patients with angiography revealing no distal run off with no option of revascularization. Also patients with failed revascularization defined as no change of clinical state with the best standard care for 4 weeks after revascularization procedure. Patients with acute ischemia and patients who are suitable for vascular reconstruction were excluded. Other exclusion criteria included hematological abnormalities as anemia $(\mathrm{Hb} \leq 10 \mathrm{~g} / \mathrm{dl})$, leukopenia (WBCs $<4,000 / \mathrm{cc}$ ), thrombocytopenia (platelets $<100,000 / \mathrm{cc}$ ), malignancies as leukemia and lymphoma, organ failure (liver or renal failure) and viral infections, such as HIV, HBV and HCV.

\section{Preparation of patients before bone marrow} aspiration:

Complete Blood Count (CBC), abdominal ultrasound and viral markers (HIV, HBV and HCV) were performed for all patients. Patients have received a recombinant human granulocyte colony stimulating factor (G-CSF) (GeneLeukim Injection from Shandong Geneleuk Biopharmaceutical Co., Ltd., Jinan, Shandong, China). Each $1 \mathrm{ml}$ vial contained $600 \mu \mathrm{g}$ Filgrastim given by subcutaneous injection in a daily dose of $5 \mu \mathrm{g} / \mathrm{kg}$ for three successive days to stimulate mononuclear cell production and mobilization. LMWH (low molecular weight heparin) was given $(1 \mathrm{mg} / \mathrm{kg}$ twice daily) subcutaneous injection to avoid the possible risks of thrombo-embolism. CBC is repeated daily to check the effect of G-CSF.

\section{Bone marrow aspiration:}

Under antiseptic precautions, a prophylactic antibiotic (1g Cefotaxim) was given via I.V. injection. A volume of $100-150 \mathrm{cc}$ of BM was aspirated from the iliac crest through anterior or posterior superior iliac spine then sent to the laboratory to separate the mononuclear cell fraction. All steps were performed under sterile conditions in a laminar flow hood (in the Clinical Pathology Department, Tanta University Hospital).

\section{Preparation of human Bone Marrow Mononu- clear Cells (BMMNCs):}

The BM aspirate prepared above was diluted at a ratio of 4:1 with clinical buffer (Clini MACS PBS/EDTA buffer $1,000 \mathrm{ml}, \mathrm{CE}$ approved for clinical use catalogue number \#700-25, from Miltenyi 
Biotec Company, Bergisch Gladbach, Germany). The diluted cell suspension was then carefully layered over $15 \mathrm{ml}$ of Ficoll-Paque (GE Electric, Pharmacia, Piscataway, NJ, USA) in a $50 \mathrm{ml}$ conical tube, and then centrifuged at $2,000 \mathrm{rpm}$ for $20 \mathrm{~min}$ at $20^{\circ} \mathrm{C}$ in a swinging out bucket rotor without brake. The upper layer was aspirated leaving the mononuclear cell layer undisturbed at the interphase containing lymphocytes, monocytes, and thrombocytes. The middle layer was carefully transferred to a new $50 \mathrm{ml}$ conical tube. The cells were then washed twice with clinical buffer, mixed gently and centrifuged at $1,200 \mathrm{rpm}$ for $15 \mathrm{~min}$ at $20^{\circ} \mathrm{C}$. Then the supernatant was carefully and completely removed. The cell pellet was suspended in the appropriate amount of clinical buffer with the final volume of $300 \mu \mathrm{L}$ of clinical buffer for up to 108 total cells.

\section{Transplantation of mononuclear cells:}

Immediately after the harvesting and centrifugation of stem cells, the mononuclear cell suspension (concentration of cells $1 \times 10^{6}-1 \times 10^{8}$ cell per $\mathrm{ml}$ ) was administered by IA (Group I) or IM (Group II) methods.

Group (I): Under antiseptic precautions with local anaesthesia or sedation. A prophylactic dose of antibiotic (Cefotaxim 1g via I.V. injection) was given. The procedure was performed in the angiosuit through an ipsilateral femoral approach by performing an arterial puncture using an 18G puncture needle. Once good arterial flow was achieved, a 40-cm-long 0.018-in. wire was used to cannulate the artery and over which an introducer sheath $6 \mathrm{~F}$ was then placed in the artery. Then a diagnostic arteriography was performed to clarify the extent of the arterial occlusion by using an iodinated contrast material (iopromide, ultravist 300, Bayer, Wayne, NJ, USA) under a mobile CARM which was manufactured by ziehm imaging GMBH with a serial number (91043). Heparin sodium $(100 \mathrm{IU} / \mathrm{kg})$ was administered systemically. Catheterization was made by a Berenstien $4 \mathrm{~F}$ $(1.8 \mathrm{~mm} * 100 \mathrm{~cm})$ angiographic catheter (produced by Angiodynamics, Inc -USA) with "road mapping" of the arteries till the point at which there was no distal run off. A volume of $50 \mathrm{ml}$ of BMCs was administered by slow infusion over $5 \mathrm{~min}$ through the angiographic catheter. Then, the sheath and the catheter were removed and hemostasis was secured by compression for $30 \mathrm{~min}$. The patients were advised not to ambulate for $3 \mathrm{~h}$ and avoid any strenuous activity for $24 \mathrm{~h}$. Patients were given aspirin before and were continued on aspirin thereafter.
Group (II): Under antiseptic precautions with general anaesthesia. A prophylactic dose of antibiotic (Cefotaxim 1g via I.V. injection) was given. A volume of $50 \mathrm{ml}$ was administered by deep injections with a $23-G$ needle into the muscles of the affected limb distributed according to the level of arterial occlusion and collaterals distribution as appeared in the angiogram. The depth of injection was $(2-2.5) \mathrm{cm}$ from the skin surface with spacing about $3-4 \mathrm{~cm}$ in between and the number of injections ranged from 35 to 55 injections.

The ulcers were surgically debrided under sterile conditions to ensure a clean base with no fibrotic or necrotic tissues. This allowed direct contact of bone marrow cells to a viable wound tissue bed. The cells were injected into the ulcer edge and the ulcer bed by using a $3 \mathrm{ml}$ syringes with 19 gauge needle. Thereafter, optimal wound care with regular dressing was performed during the follow-up period.

Group (III): Patients were subjected to proper control of the risk factors and the best medical treatment according to TASC-II with proper wound management.

\section{Follow-up:}

All patients were examined before, 30 days, 90 days, and 6 months after BMC transplantation for signs of improvement of tissue perfusion, amputation free survival, improvement of wound healing, disappearance or improvement of rest pain according to VAS, increased pain-free walking distance and Improvement of the ankle brachial index. In both Group I, II angiography was done 6 month after stem cell therapy to detect the formation of new collateral vessels. Also, muscle biopsy with tru-cut needle (16) gauge was taken before and 3 month after intervention to detect neo-angiogenesis by immunohistochemistry.

\section{Statistical analysis:}

Data were fed to the computer and analyzed using software package used for statistical analysis (IBM SPSS Version 20.0 for Windows, SPSS, Chicago, IL, USA). Qualitative data were described using number and percent. Quantitative data were described using range (minimum and maximum), mean, standard deviation and median.

\section{Results}

The baseline characteristics of all patients included in the study were including age, sex, asso- 
ciated risk factors and co-morbidities, clinical presentation (Table 1).

\section{Clinical responses to G-CSF:}

After G-CSF administration in Groups (I, II), the WBCs count was increased indicating an increase in mononuclear cell production and mobilization. The maximum WBCs count was 46,200/cc and the minimum was $21,500 / \mathrm{cc}$ (with mean value of 33,500$)$.

\section{Primary outcome:}

\section{1-Limb salvage:}

The total limb salvage rate at the 6 th month after stem cell therapy was significant between the studied groups in comparison with the control group (Table 2). In Group (I) the total number of saved limbs was 9 limbs (81.8\%). In Group (II) the total number of saved limbs was 8 limbs (72.7\%). In Group (III) the total number of saved limbs was 3 patients $(27.7 \%)$.

\section{2- Therapy related complications:}

There were no procedure related mortality or thrombo-embolic complications. Minor complications were reported after SCT in both groups which were self-limited and resolved within 2 weeks (Table 3).

\section{Secondary outcomes:}

\section{- Effect of SCT on rest pain:}

By the Visual Analogue Scale (VAS), the severity of rest pain was assessed before and after SCT (Table 4). In Group (I) two patients were excluded from the start as rest pain can't be assessed due to marked neuropathy. At the first month, one patient died and the other 12 patients showed a significant decrease in the VAS mean from $6.92 \pm 1.89$ to $5.17 \pm 1.59(p$-value $=0.005)$. At the 3 rd month, two patients had a major amputation (AKA) and three patients were lost during the follow-up. The remaining seven patients showed a continuous improvement of the rest pain and the VAS mean was significantly decreased to $3.13 \pm 2.1(p$-value $=0.011)$ and to $1.25 \pm 1.49$ at the 6th month, $(p$-value $=0.012)$.

In Group (II) at the first month, one patient died and the remaining 14 patients showed a significant change in the VAS as the mean was significantly decreased from $6.27 \pm 2.49$ to $4.79 \pm 2.36$ ( $p$-value $=0.002)$. At the $3 \mathrm{rd}$ month, another patient died, three patients had a major amputation (AKA) and two other patients were lost during the followup. The remaining eight patients showed a continuous improvement of the rest pain and the VAS mean was significantly decreased to $3.88 \pm 1.64$ ( $p$ - value $=0.011)$ and to $1.88 \pm 1.46(p$-value $=0.011)$ at the 6 th month.

While in Group (III) after the first month, one patient died. In the remaining 14 patients, the VAS mean changed from $6.27 \pm 1.71$ to $5.71 \pm 1.77$ ( $p$ value $=0.170$ ). At the $3 \mathrm{rd}$ month, another patient died, 4 patients had a major amputation (AKA) and 2 patients were lost during the follow-up. The VAS mean in the remaining 7 patients was changed to $4.29 \pm 1.89$ points $(p$-value $=0.081)$. At the 6 th month, other four patients had a major amputation. The VAS mean in the remaining 3 patients was changed to $3.6 \pm 0.55$ points $(p$-value $=0.180)$.

In comparison between the studied groups at the 6th month after intervention (Table 5), there was a significant improvement as regarding the rest pain $(p=0.023)$ while there was no significant difference between both Groups I, II. Patients in both groups showed significant improvement and the means of VAS were $1.25 \pm 1.49,1.88 \pm 1.46$ respectively $(p=0.431)$.

\section{- Physical activity and pain -free walking distance (Table 6):}

In Group (I), two patients were excluded from the start as they were unable to move due to contralateral cerebral insult. At the first month, one patient died and the other 12 patients showed a significant increase in the walking distance as the mean was changed from $22.69 \pm 10.53$ to 80.83 \pm 15.05 ( $p$-value $=0.002)$. At the 3 rd month, two patients had a major amputation (AKA) and three patients were lost during the follow-up. In the remaining 7 patients there was a continuous improvement and the pain free walking distance was significantly increased to $170.0 \pm 21.38$ ( $p$-value $=0.011)$ and to $271.25 \pm 42.24)$ at the ${ }^{6 \text { th }}$ month $(p$ value $=0.012$ ).

In Group (II) at the first month, one patient died and the remaining 14 patients showed improvement in the physical activity as the mean of the walking distance was significantly increased from $26.67 \pm 9.57$ to $73.93 \pm 18.21$ ( $p$-value $=0.001$ ). At the $3 \mathrm{rd}$ month, another patient died, three patients had a major amputation (AKA) and two other patients were lost during the follow-up. The remaining 8 patients showed a continuous improvement and the pain free walking distance mean was significantly increased to $177.5 \pm 19.82(p$-value $=$ $0.011)$ and to $266.25 \pm 26.15$ at the 6 th month ( $p$ value $=0.012$ ).

While in Group (III) at the first month, one patient died. In the remaining 14 patients, the pain 
free walking distance mean significantly changed from $25.83 \pm 6.69$ to $41.82 \pm 12.5$ ( $p$-value $=0.008$ ). At the 3 rd month, another patient died, 4 patients had a major amputation (AKA) and 2 patients were lost during the follow-up. The pain free walking distance mean changed in the remaining seven patients to $65.0 \pm 12.91$ ( $p$-value $=0.068)$. At the $6^{\text {th }}$ month, other four patients had a major amputation. The pain free walking distance mean in the remaining 3 patients changed to $82.5 \pm 12.85$ ( $p$-value $=$ 0.068 ).

Comparison between the studied groups at the 6th month after intervention (Table 7) showed a significant improvement as regarding the physical activity and the walking distance $(p=0.010)$. While there was no significant difference between both Groups I, II. Patients in both groups showed significant improvement and the means of the pain free walking distance were $271.25 \pm 42.24,266.25 \pm$ 26.15 respectively $(p=0.832)$.

\section{- Ankle brachial index (ABI) (Table 8):}

Significant improvement of the ABI was reported after SCT. In Group (I) at the first month, one patient died and the other 14 patients were improved as the mean was increased from $0.35 \pm 0.11$ to $0.46 \pm 0.11$ ( $p$-value=0.017). At the 3 rd month, two patient had a major amputation (AKA) and three patients were lost during the follow-up. In the remaining 9 patients the $\mathrm{ABI}$ mean was significantly increased to $0.6 \pm 0.09(p$-value $=<0.001)$ and to $0.74 \pm 0.05$ at the 6 th month $(p$-value $=<0.001)$.

In Group (II) at the first month, one patient died and the mean of ABI in the remaining 14 patients was increased from $0.38 \pm 0.10$ to $0.43 \pm 0.12$ ( $p$-value $=0.478)$. At the $3 \mathrm{rd}$ month, another patient died, three patient had a major amputation (AKA) and two other patients were lost during the followup. In the remaining 8 patients the $\mathrm{ABI}$ mean was significantly increased to $0.53 \pm 0.09$ ( $p$-value $=$ $0.001)$ and to $0.75 \pm 0.05$ at the 6 th month ( $p$-value $=<0.001)$.

While in Group (III) at the first month, one patient died. In the remaining 14 patients, the ABI mean showed a non-significant change from $0.36 \pm$ 0.1 to $0.41 \pm 0.06$ ( $p$-value $=0.543$ ). At the $3 \mathrm{rd}$ month, another patient died, 4 patients had a major amputation (AKA) and 2 patients were lost during the follow-up. The ABI mean changes was nonsignificant as it became $0.46 \pm 0.09$ ( $p$-value $=0.487)$. At the 6 th month, other four patients had a major amputation. The ABI mean in the remaining 3 patients was non significantly changed to $0.51 \pm 0.09$ $(p$-value $=0.232)$.

Comparison between the studied groups at the 6th month after intervention (Table 9) showed a significant improvement as regarding the $\mathrm{ABI}$ $(p=<0.001)$. While there was no significant difference between both Groups I, II. Patients in both groups showed significant improvement and the means of the ABI were $0.74 \pm 0.05,0.75 \pm 0.05$ respectively $(p=0.908)$.

\section{- Ischemic ulcer healing in the studied groups:}

Significant improvement in ischemic wound healing was noticed at the 6 th month in a comparison between the studied groups ( $p=0.002$ ) (Table 10). All patients who continue follow-up and had ischemic ulcers or tissue gangrene underwent a minor amputation or a surgical debridement to improve wound healing. In Group (I); complete ulcer healing was occurred in six patients $(75 \%)$ Fig. (1). In Group (II); complete ulcer healing was occurred in the five patients (83.3\%) Fig. (2). While in Group (III); the three patients who avoid major amputation showed only partial wound healing as complete healing did not occur in any patient.

\section{- Angiography was done at the $6^{\text {th }}$ month in patients who continue the follow-up period in both Groups (I, II): Table (11):}

Group (I) angiography was done in 7 patients $(46.6 \%)$. There was a significant new collaterals formation in five patients (71.5\%) Fig. (3). Group (II) angiography was done after 6 month in seven $(46.6 \%)$ patients. Significant new collaterals formation was found in six patients (85.7\%) Fig. (4).

\section{- Results of muscle biopsy as regarding the neo- angiogenesis in Groups $(I, I I)$ at the 3 rd month after SCT: Table (12):}

There was no significant difference between both groups as regarding neo-angiogenesis ( $p=$ 1.000). In Group (I) muscle biopsy was taken in nine patients Fig. (5). Eight patients (88.9\%) showed significant neo-angiogenesis and only one patient $(11.1 \%)$ didn't show a significant neoangiogenesis. While in Group (II) muscle biopsy was taken in eight patients. Seven patients $(87.5 \%)$ showed significant neo-angiogenesis.

\section{Intra-arterial versus intramuscular application:}

Both procedures were well tolerated without peri-procedural complications. There were no differences in IA versus IM application in either endpoint. 
Table (1): Baseline characteristics of all patients included in the study were including age, sex, associated risk factors and co-morbidities, clinical presentation.

\begin{tabular}{|c|c|c|c|c|c|c|c|}
\hline & \multicolumn{2}{|c|}{$\begin{array}{l}\text { Group I } \\
(\mathrm{n}=15)\end{array}$} & \multicolumn{2}{|c|}{$\begin{array}{l}\text { Group II } \\
(\mathrm{n}=15)\end{array}$} & \multicolumn{2}{|c|}{$\begin{array}{c}\text { Group III } \\
(\mathrm{n}=15)\end{array}$} & \multirow{2}{*}{$p$} \\
\hline & No & $\%$ & No & $\%$ & No & $\%$ & \\
\hline Sex (male) & 9 & 60.0 & 8 & 53.3 & 8 & 53.3 & 0.914 \\
\hline Age (years) & 61.5 & 12.70 & 67. & $=8.79$ & & 10.74 & 0.280 \\
\hline \multicolumn{8}{|c|}{ Risk factors and associated co-morbidities } \\
\hline Smoking & 5 & 33.3 & 5 & 33.3 & 6 & 33.3 & 0.908 \\
\hline Hyperlipidema & 6 & 40.0 & 5 & 33.3 & 8 & 33.3 & 0.529 \\
\hline Hypertension & 11 & 73.3 & 10 & 66.7 & 9 & 66.7 & 0.741 \\
\hline Diabetes & 7 & 46.7 & 7 & 46.7 & 7 & 46.7 & 1.000 \\
\hline Stroke & 2 & 13.3 & 4 & 26.7 & 5 & 26.7 & ${ }^{\mathrm{MC}} p=0.565$ \\
\hline Heart disease & 3 & 20.0 & 5 & 33.3 & 8 & 33.3 & 0.158 \\
\hline \multicolumn{8}{|c|}{ Clinical presentation } \\
\hline Rest pain & 8 & 53.3 & 7 & 46.7 & 6 & 46.7 & 0.765 \\
\hline Toe gangrene & 7 & 46.7 & 8 & 53.3 & 9 & 53.3 & 0.765 \\
\hline Forefoot gangrene & 3 & 20.0 & 1 & 6.7 & 1 & 6.7 & $\mathrm{MC}_{p}=0.597$ \\
\hline Ischemic ulcer & 3 & 20.0 & 4 & 26.7 & 4 & 26.7 & $\mathrm{MCp}=1.000$ \\
\hline
\end{tabular}

Table (2): Comparison between the studied groups according to limb salvage.

\begin{tabular}{|c|c|c|c|c|c|c|c|}
\hline \multirow{2}{*}{ Limb state } & \multicolumn{2}{|c|}{$\begin{array}{l}\text { Group I } \\
(n=11)\end{array}$} & \multicolumn{2}{|c|}{$\begin{array}{c}\text { Group II } \\
(\mathrm{n}=11)\end{array}$} & \multicolumn{2}{|c|}{$\begin{array}{l}\text { Group III } \\
(\mathrm{n}=11)\end{array}$} & \multirow{2}{*}{$p_{1}$} \\
\hline & No & $\%$ & No & $\%$ & No & $\%$ & \\
\hline Total salvage & 9 & 81.8 & 8 & 72.7 & 3 & 27.3 & $\mathrm{MC}_{p}=0.015^{*}$ \\
\hline Salvage with minor amputation & 6 & 54.5 & 3 & 27.3 & 1 & 9.1 & \\
\hline Major amputation & 2 & 18.2 & 3 & 27.3 & 8 & 72.7 & $\mathrm{MC}_{p}=0.015^{*}$ \\
\hline Excluded: & \multicolumn{2}{|c|}{$(n=4)$} & \multicolumn{2}{|c|}{$(n=4)$} & \multicolumn{2}{|c|}{$(n=4)$} & \\
\hline Died & 1 & 25.0 & 2 & 50.0 & 2 & 50.0 & $\mathrm{MC}_{p}=1.000$ \\
\hline Lost follow-up & 3 & 75.0 & 2 & 50.0 & 2 & 50.0 & \\
\hline
\end{tabular}

Table (3): Comparison between the studied groups according to therapy related complications.

\begin{tabular}{|c|c|c|c|c|c|}
\hline \multirow{2}{*}{ Therapy related adverse events } & \multicolumn{2}{|c|}{ Group I $(n=15)$} & \multicolumn{2}{|c|}{ Group II $(n=15)$} & \multirow{2}{*}{$\mathrm{FE}_{p}$} \\
\hline & No & $\%$ & No & $\%$ & \\
\hline Injection site pain & 0 & 0.0 & 3 & 20.0 & 0.224 \\
\hline Hematoma & 3 & 20.0 & 2 & 13.3 & 1.000 \\
\hline Edema & 0 & 0.0 & 4 & 26.7 & 0.100 \\
\hline Fever & 2 & 13.3 & 3 & 20.0 & 1.000 \\
\hline
\end{tabular}

Table (4): Rest pain changes as regarding the Visual Analogue Scale (VAS).

\begin{tabular}{|c|c|c|c|c|}
\hline Pain score & Pre & 1 month & 3 month & 6 month \\
\hline Group I: & $(n=13)$ & $(n=12)$ & $(n=\pi)$ & $(n=7)$ \\
\hline Mean \pm SD. & $6.92 \pm 1.89$ & $5.17 \pm 1.59$ & $3.13 \pm 2.10$ & $1.25 \pm 1.49$ \\
\hline$p_{\text {pre }}$ & & $0.005^{*}$ & $0.011 *$ & $0.012 *$ \\
\hline Group II: & $(n=15)$ & $(n=14)$ & ${ }_{(n=8)}$ & $(n=8)$ \\
\hline Mean \pm SD. & $6.27 \pm 2.49$ & $4.79 \pm 2.36$ & $3.88 \pm 1.64$ & $1.88 \pm 1.46$ \\
\hline$p_{\text {pre }}$ & & $0.002 *$ & $0.011 *$ & $0.011 *$ \\
\hline Group III: & $(n=15)$ & $(n=14)$ & $(n=7)$ & $(n=3)$ \\
\hline Mean \pm SD & $6.27 \pm 1.71$ & $5.71 \pm 1.77$ & $4.29 \pm 1.89$ & $3.60 \pm 0.55$ \\
\hline$p_{\text {pre }}$ & & 0.170 & 0.081 & 0.180 \\
\hline
\end{tabular}


Table (5): Comparison between the studied groups after 6 month as regarding (VAS).

\begin{tabular}{lccccc}
\hline VAS at the 6th month & Group I $(\mathrm{n}=7)$ & Group II $(\mathrm{n}=8)$ & Group III $(\mathrm{n}=3)$ & $\mathrm{H}$ & $p$ \\
\hline Mean \pm SD. & $1.25 \pm 1.49$ & $1.88 \pm 1.46$ & $3.60 \pm 0.55$ & 7.555 & $0.023^{*}$ \\
$p$ & $p_{1}=0.431, p_{2}=0.007^{*}, p_{3}=0.043^{*}$ & & \\
\hline
\end{tabular}

p1: $p$-value for comparing between Groups (I) and (II).

2: $p$-value for comparing between Groups (1) and (III).

$p 3: p$-value for comparing between Groups (II) and (III).

Table (6): Physical activity as regarding the pain free walking distance in the studied groups.

\begin{tabular}{lllll}
\hline Walking distance & Pre & 1 month & 3 month & 6 month \\
\hline Group I: & $(\mathrm{n}=13)$ & $(\mathrm{n}=12)$ & $(\mathrm{n}=7)$ & $(\mathrm{n}=7)$ \\
Mean \pm SD. & $22.69 \pm 10.53$ & $80.83 \pm 15.05$ & $170.0 \pm 21.38$ & $271.25 \pm 42.24$ \\
$p_{\text {pre }}$ & & $0.002^{*}$ & $0.011^{*}$ & $0.012^{*}$ \\
Group II: & $(\mathrm{n}=15)$ & $(\mathrm{n}=14)$ & $(\mathrm{n}=8)$ & $(\mathrm{n}=8)$ \\
Mean \pm SD. & $26.67 \pm 9.57$ & $73.93 \pm 18.21$ & $177.50 \pm 19.82$ & $266.25 \pm 26.15$ \\
$p_{\text {pre }}$ & & $0.001^{*}$ & $0.011^{*}$ & $0.012^{*}$ \\
Group III: & $(\mathrm{n}=15)$ & $(\mathrm{n}=14)$ & $(\mathrm{n}=7)$ & $(\mathrm{n}=3)$ \\
Mean \pm SD. & $25.83 \pm 6.69$ & $41.82 \pm 12.50$ & $65.0 \pm 12.91$ & $82.50 \pm 12.58$ \\
$p_{\text {pre }}$ & & $0.008^{*}$ & 0.068 & 0.068 \\
\hline
\end{tabular}

Table (7): Comparison between the studied groups after 6 month as regarding the physical activity and the walking distance.

\begin{tabular}{lccccc}
\hline Walking distance & Group I $(\mathrm{n}=7)$ & Group II $(\mathrm{n}=8)$ & Group III $(\mathrm{n}=3)$ & $\mathrm{H}$ & $p$ \\
\hline Mean \pm SD. & $271.25 \pm 42.24$ & $266.25 \pm 26.15$ & $82.50 \pm 12.58$ & $9.257^{*}$ & $0.010^{*}$ \\
$p$ & $p_{1}=0.832, p_{2}=0.004^{*}, p_{3}=0.007^{*}$ & & \\
\hline
\end{tabular}

1: $p$-value for comparing between Groups (I) and (II).

2: $p$-value for comparing between Groups (I) and (III).

$p 3$ : $p$-value for comparing between Groups (II) and (III).

Table (8): ABI changes in the studied groups.

\begin{tabular}{lllll}
\hline ABPI & Pre & 1 month & 3 month & 6 month \\
\hline Group I: & $(\mathrm{n}=15)$ & $(\mathrm{n}=14)$ & $(\mathrm{n}=9)$ & $(\mathrm{n}=9)$ \\
Mean \pm SD. & $0.35 \pm 0.11$ & $0.46 \pm 0.11$ & $0.60 \pm 0.09$ & $0.74 \pm 0.05$ \\
$p_{\text {pre }}$ & & $0.017^{*}$ & $0.001^{*}$ & $<0.001^{*}$ \\
Group II: & $(\mathrm{n}=15)$ & $(\mathrm{n}=14)$ & $(\mathrm{n}=8)$ & $(\mathrm{n}=8)$ \\
Mean \pm SD. & $0.38 \pm 0.10$ & $0.43 \pm 0.12$ & $0.53 \pm 0.9$ & $0.75 \pm 0.05$ \\
$p_{\text {pre }}$ & & 0.478 & $0.001 *$ & $<0.001^{*}$ \\
Group III: & $(\mathrm{n}=15)$ & $(\mathrm{n}=14)$ & $(\mathrm{n}=7)$ & $(\mathrm{n}=3)$ \\
Mean \pm SD. & $0.36 \pm 0.10$ & $0.41 \pm 0.06$ & $046 \pm 0.09$ & $0.51 \pm 0.09$ \\
$p_{\text {pre }}$ & & 0.543 & 0.487 & 0.232 \\
\hline
\end{tabular}

Table (9): Comparison between the different groups according to ABI.

\begin{tabular}{lccccc}
\hline ABPI & Group I (n=9) & Group II (n=8) & Group III (n=3) & $F$ & $p$ \\
\hline Mean \pm SD & $0.74 \pm 0.05$ & $0.75 \pm 0.05$ & $0.52 \pm 0.19$ & $0.001^{*}$ \\
$p$ & \multicolumn{1}{c}{$p_{1}=0.908, p_{2}<0.001 *, p_{3}<0.001 *$} & \\
\hline
\end{tabular}

p1: $p$-value for comparing between Groups (I) and (II).

2: $p$-value for comparing between Groups (I) and (III).

$p 3$ : $p$-value for comparing between Groups (II) and (III). 
Table (10): Comparison between the studied groups according to wound healing.

\begin{tabular}{|c|c|c|c|c|c|c|c|c|}
\hline \multirow{2}{*}{ Wound healing } & \multicolumn{2}{|c|}{ Group I } & \multicolumn{2}{|c|}{ Group II } & \multicolumn{2}{|c|}{ Group III } & \multirow{2}{*}{$x^{2}$} & \multirow{2}{*}{$\mathrm{MC}_{p}$} \\
\hline & No & $0 / 0$ & No & $0 \% 1$ & No & $0 / 0$ & & \\
\hline Ischemic wound & \multicolumn{2}{|c|}{$(\mathrm{n}=8)$} & \multicolumn{2}{|c|}{$(n=6)$} & \multicolumn{2}{|c|}{$(\mathrm{n}=3)$} & & \\
\hline Complete healing & 6 & 75 & 5 & 83.3 & 0 & 0.0 & $11.089^{*}$ & $0.002 *$ \\
\hline Partial wound healing & 2 & 25 & 1 & 16.7 & 3 & 100.0 & & \\
\hline$p$ & \multicolumn{6}{|c|}{$p_{1}=-, \mathrm{FE} p_{2}=0.006^{*}, \mathrm{FE}_{p_{3}}=0.012^{*}$} & & \\
\hline Excluded & \multicolumn{2}{|c|}{$(n=7)$} & \multicolumn{2}{|c|}{$(\mathrm{n}=9)$} & \multicolumn{2}{|c|}{$(\mathrm{n}=12)$} & & \\
\hline Died & 1 & 14.3 & 2 & 22.2 & 2 & 16.7 & 5.837 & 0.472 \\
\hline Major amputation & 2 & 28.6 & 3 & 33.3 & 8 & 66.7 & & \\
\hline Lost follow-up & 3 & 42.9 & 2 & 22.2 & 2 & 16.7 & & \\
\hline No ischemic wound & 1 & 14.3 & 2 & 22.2 & 0 & 0.0 & & \\
\hline
\end{tabular}

Table (11): Comparison between Groups (I, II) according to new collaterals in the angiogram.

\begin{tabular}{|c|c|c|c|c|c|c|}
\hline \multirow{2}{*}{$\begin{array}{l}\text { New collaterals in } \\
\text { the angiogram }\end{array}$} & \multicolumn{2}{|c|}{$\begin{array}{c}\text { Group I } \\
(\mathrm{n}=7)\end{array}$} & \multicolumn{2}{|c|}{$\begin{array}{c}\text { Group II } \\
(\mathrm{n}=7)\end{array}$} & \multirow{2}{*}{$x^{2}$} & \multirow[t]{2}{*}{$\mathrm{MC}_{p}$} \\
\hline & No & $\%$ & No & $\%$ & & \\
\hline New collaterals & 5 & 71.5 & 6 & 85.7 & 1.134 & 0.957 \\
\hline No collaterals & 2 & 28.5 & 1 & 14.3 & & \\
\hline Excluded & \multicolumn{2}{|c|}{$(n=8)$} & \multicolumn{2}{|c|}{$(n=8)$} & & \\
\hline Died & 1 & 12.5 & 2 & 25.0 & 1.322 & 1.000 \\
\hline Major amputation & 2 & 25.0 & 3 & 37.5 & & \\
\hline Lost follow-up & 3 & 37.5 & 2 & 25.0 & & \\
\hline Refuse to do & 2 & 25.0 & 1 & 12.5 & & \\
\hline
\end{tabular}

Table (12): Comparison between groups (I) \& (II) according to neo-angiogenesis.

\begin{tabular}{|c|c|c|c|c|c|c|}
\hline \multirow{2}{*}{$\begin{array}{l}\text { Histopathology } \\
\text { neo-angiogenesis }\end{array}$} & \multicolumn{2}{|c|}{$\begin{array}{c}\text { Group I } \\
(\mathrm{n}=9)\end{array}$} & \multicolumn{2}{|c|}{$\begin{array}{l}\text { Group II } \\
(\mathrm{n}=8)\end{array}$} & \multirow{2}{*}{$\chi^{2}$} & \multirow{2}{*}{$p$} \\
\hline & No & $\%$ & No & $\%$ & & \\
\hline Neo-angiogenesis & 8 & 88.9 & 7 & 87.5 & 0.008 & $\mathrm{FE}_{p}=$ \\
\hline Not present & 1 & 11.1 & 1 & 12.5 & & 1.000 \\
\hline Excluded & \multicolumn{2}{|c|}{$(n=6)$} & \multicolumn{2}{|c|}{$(n=7)$} & & \\
\hline Died & 1 & 16.7 & 2 & 28.6 & 0.844 & $\mathrm{MC}_{p}=$ \\
\hline Major amputation & 2 & 33.3 & 3 & 42.9 & & 1.000 \\
\hline Lost follow-up & 3 & 50.0 & 2 & 28.6 & & \\
\hline
\end{tabular}
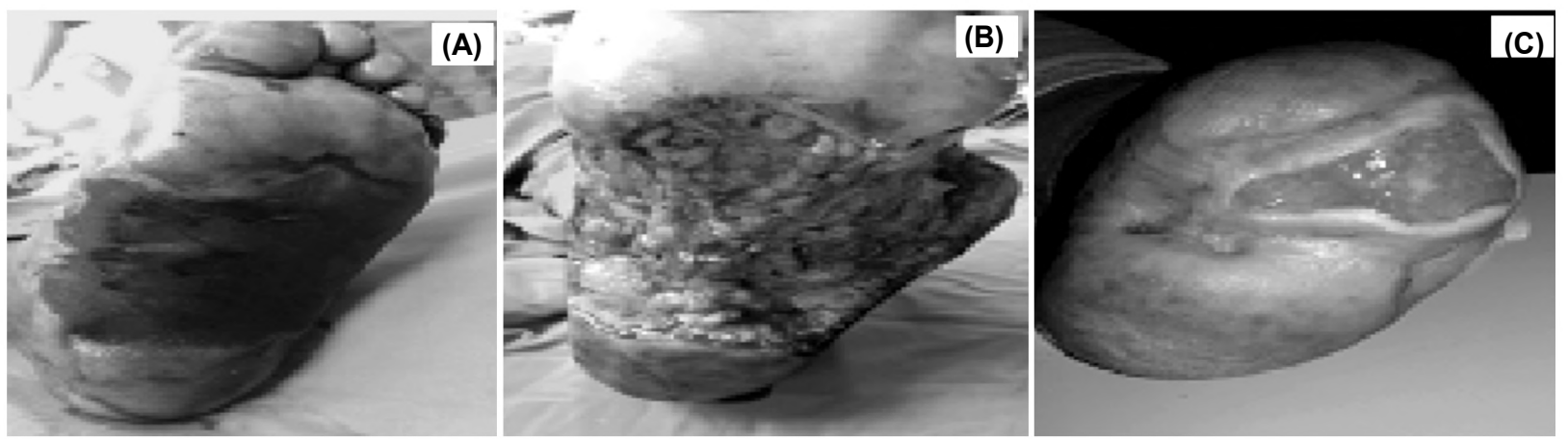

Fig. (1): Photo (A) Tissue gangrene in the sole, Photo (B) After surgical debridement and Photo (C) Partial healing stump after forefoot amputation in patient in Group II.
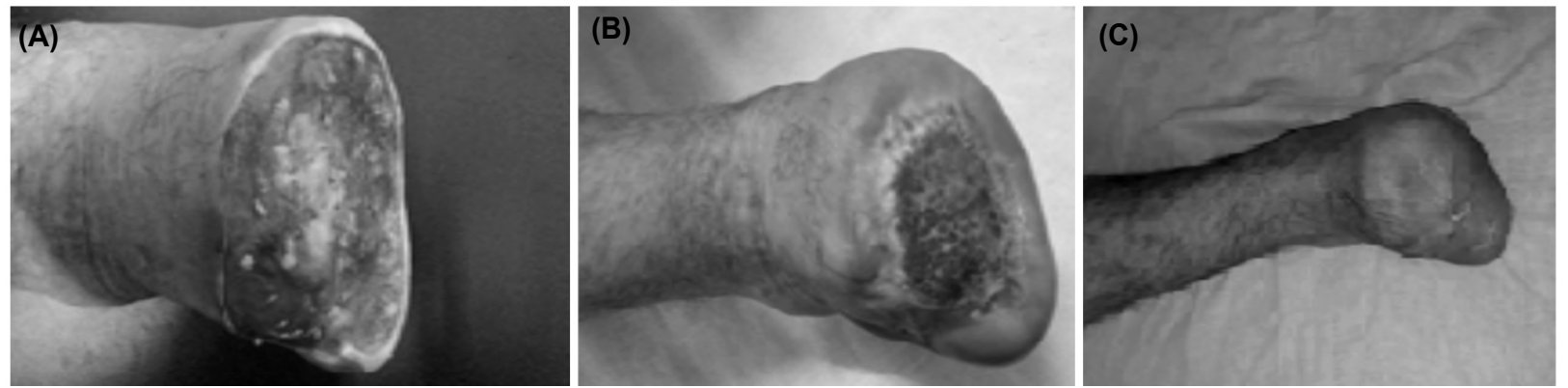

Fig. (2): Healing stump after forefoot amputation in case of CLI in the first 6 month as Photo (A) After 1 month, Photo (B) After 3 month while Photo (C) Complete healing after 6 month. 

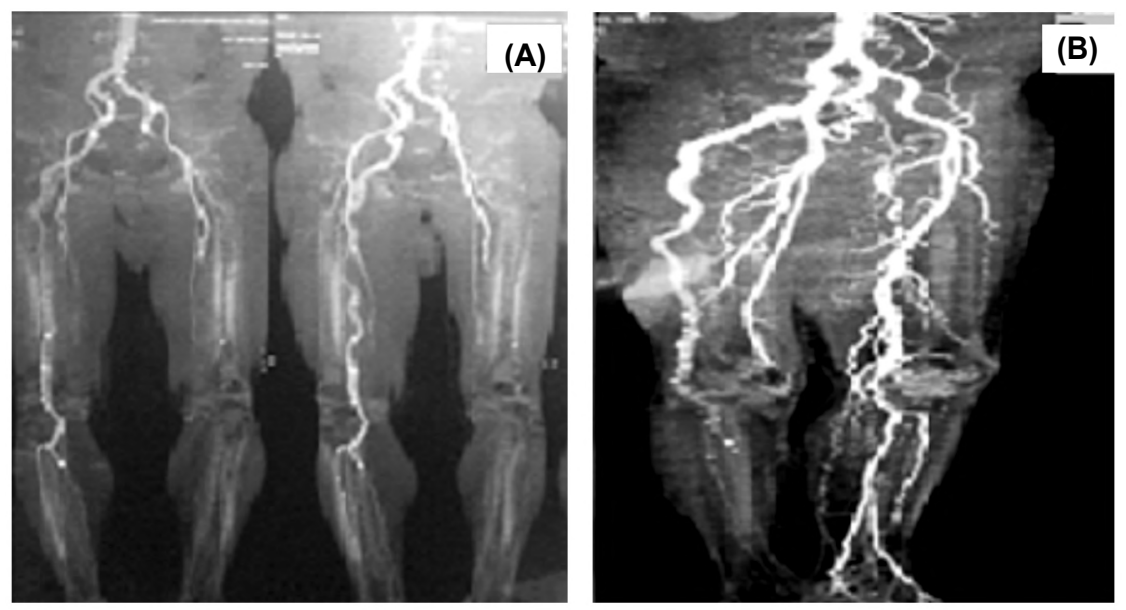

Fig. (3): Photo (A): Angiogram showing complete occlusion of the left superficial femoral artery. (B): Showing new collateral formation in the left lower limb 6 month after stem cell therapy.
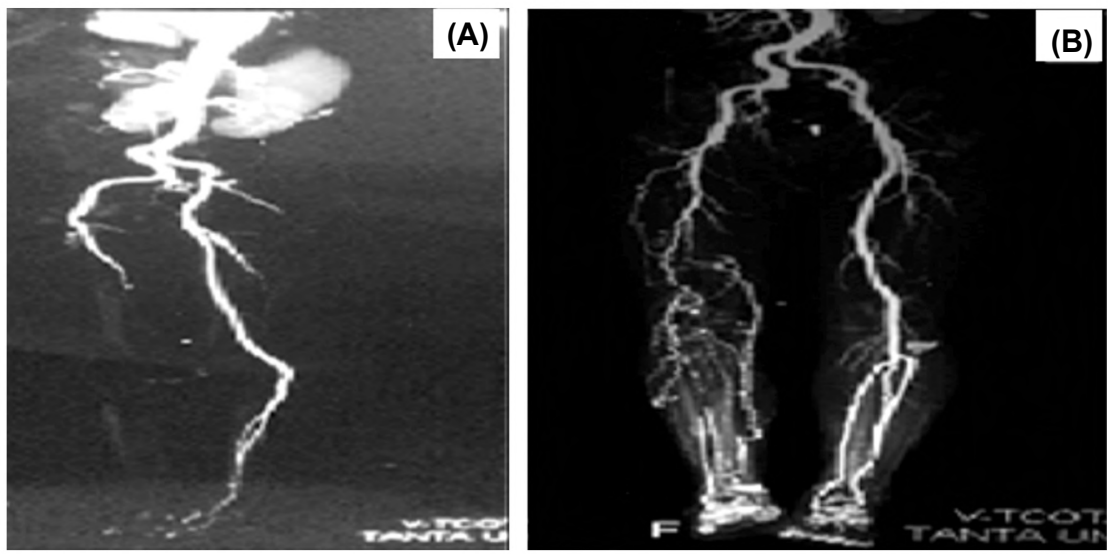

Fig. (4): Photo (A): Angiogram showing complete occlusion of right superficial femoral artery. Photo (B): Showing new collateral formation in the right lower limb 6 month after stem cell therapy.
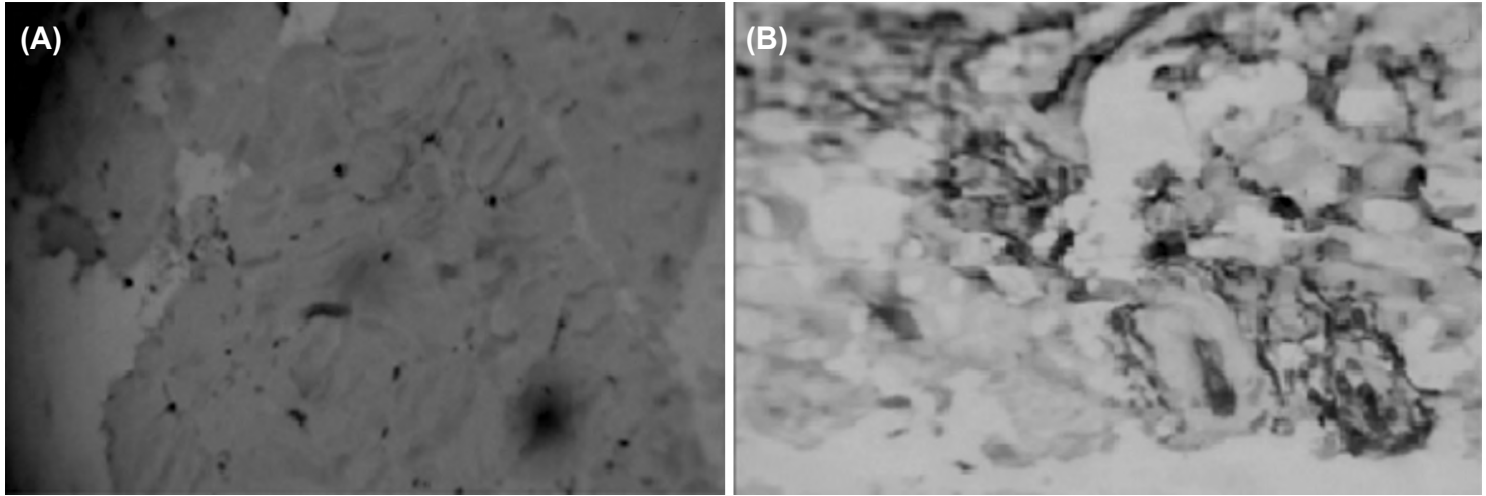

Fig. (5): (A) Tru cut muscle biopsy stained by CD $34^{+}$stain by immunohistochemistry at the time of stem cells injection showed no angiogenesis in a patient in Group (I). (B) Second biopsy 3 months after SCT showed neo angiogenesis in the same patient.

\section{Discussion}

The main challenge in the therapeutic approach to non-reconstructable critical limb ischemia is to regain an effective limb reperfusion in absence of convenient patent distal arterial bed for conventional reconstruction. The present study compare the safety and efficiency of autologous transplantation of BM-derived mononuclear cells after mobilization with G-CSF either by intra-arterial or intramuscular routes of administration. The main findings were that both routes are effective and comparable for limb salvage and improving the ischemic tissue perfusion without major complications.

At the 6 th month, the total limb salvage rate in Group I was $9(81.8 \%)$ and in Group II, was 8 patients $(72.7 \%)$. Madaric et al., [7] found that the overall amputation free survival rate was $63 \%$ 
(39/62 patients) after 12 months. Ismail et al., [8] showed that the total limb salvage was 16 patients $(80 \%)$. Klepanec et al., [9] showed that the prevalence of limb salvage was $73 \%$.

Therapy related adverse events had occurred without procedure related mortality or thromboembolic complications. Similarly, Ismail et al., [8] showed that no major complications were reported; only some minor complications occurred which resolved spontaneously. Injection site pain occurred in 5 patients $(25 \%)$. Small intramuscular hematoma occurred in one patient $(5 \%) .3$ patients $(15 \%)$ developed mild edema. Low grade fever appeared in 2 patients (10\%). In Heo et al., [2]. No patient's experienced procedure-related complications or major systemic complications during the hospital stay. In Madaric et al., [7] no infection, local swelling, or other adverse effects associated with cell application were observed during the follow-up period.

In the present study, in Group I, the VAS mean was significantly decreased from 6.92 to 1.25 points at the 6 th month. In Group II, the VAS mean was significantly decreased from 6.27 to 1.88 points at the 6 th month while there were no significant changes in the control group. In Heo et al., [2]. By Numerical Rating Scale (NRS). The mean pain score was 5.5 points. Pain scores were significantly decreased at the 6 th month $(1.4, p<0.001)$. In Madaric et al., [7]. the VAS decreased from 4.3 study to 1.6 at 6 month. In Ismail et al., [8] . by the use of Visual Analogue Scale (VAS), there was an improvement in the rest pain after SCT. At the 6 th month, the VAS was 3.3 points.

In the present study, in Group I, the pain free walking distance mean was significantly changed from 22.69 to 271.25 meters and from 26.67 to 266.25 meters at the 6 th month in Group II. Similarly, in Ismail et al., [8] . The pain free walking distance increased from 85.3 meters to 163.5 meters ( $p$-value $=0.028)$. Amann et al., [9] reported a reduction in analgesics consumption by $62 \%$ and an improvement in walking distance in non-amputees from zero to 40 meters.

In the present study, in Group I, ABI was significantly increased from 0.35 to $0.74 \mathrm{mmHg}$ and from 0.38 to $0.75 \mathrm{mmHg}$ in Group II at the $6^{\text {th }}$ month. Similarly, Ismail et al., [8] approved that $\mathrm{ABI}$ increased from 0.27 to $0.71 \mathrm{mmHg}$ in the first 6 months and to $0.72 \mathrm{mmHg}$ after one year. On the other hand, Heo et al., [2] showed that the ABI was increased from 0.76 to $0.78 \mathrm{mmHg}$ after 3 months and to $0.81 \mathrm{mmHg}$ after 6 months, but the difference was not significant however, ABI was significantly improved from $0.18 \mathrm{mmHg}$ to $0.33 \mathrm{mmHg}$ after 6 months.

As regarding wound healing after 6 month, complete healing occurred in six patients $(75 \%)$ in Group I and in five patients (83.3\%) in Group II. Similarly In Madaric et al., [7] at 6 month the ischemic ulcer size was changed from $6.5 \pm 5.9 \mathrm{~cm}^{2}$ to $3.3 \pm 5.1 \mathrm{~cm}$. Then at one year the ischemic ulcer size was $1.7 \pm 2.5 \mathrm{~cm}^{2}$ with $p$-value $<0.001$. In Heo et al., [2]. Among 46 limbs, 17 limbs had an ischemic ulcer. The ischemic ulcers completely healed in 11 limbs $(64.7 \%)$ and improved markedly in 2 limbs (11.7\%) after 6 months. During the followup period, the ischemic ulcer of 4 limbs $(23.5 \%)$ did not change and there was only 1 unplanned toe amputation. In Ismail et al., study [8] three patients $(75 \%)$, out of the four who presented with ischemic ulcer, showed healing of the ulcer in the first 6 months.

In the present study angiography was done at the 6 th month of follow-up for new collateral formation in both Groups (I, II). In Group I, angiography was done in 7 patients $(46.6 \%)$. There was significant new collaterals formation in five patients $(71.5 \%)$. In Group II, angiography was done in seven $(46.6 \%)$ patients. Significant new collaterals formation was found in six patients (85.7\%). Similarly, Ismail et al., [8] angiography was done after stem cell therapy in 12 patients. 9 patients $(75 \%)$ showed angiogenesis and 3 patients $(25 \%)$ did not show angiogenesis which agreed with our results. Kirana et al., [10] reported the presence of angiogenesis which was detected in some, but not all patients by angiography.

In present study, eight patients (88.9\%) in Group I showed significant neo-angiogenesis and only one patient (11.1\%) didn't show a significant neoangiogenesis despite clinical improvement. In Group II, seven patients (87.5\%) showed significant neo-angiogenesis and only one patient $(12.5 \%)$ didn't show neo-angiogenesis. Similarly De Vriese et al., [11] reported that 12 weeks after SCT Capillary surface area in the gastrocnemius muscle biopsy increased from $0.61 \%$ to $0.73 \%(p<0.05)$.

\section{Conclusion:}

This study included a new emerging modality for management of patients with critical lower limb ischemia with no distal run off according to patient risk stratification. There was no difference between autologous transplantation of stem cell either by intra-arterial or intra-muscular administration. Both routes are simple, safe and effective. 
They can improve the limb salvage rates and quality of life without therapy related adverse effects.

Acknowledgments: This research was carried out without funding.

Conflicts of interest: No conflicts of interest declared.

Authors' Contributions: All authors had equal role in design, work, statistical analysis and manuscript writing.

\section{References}

1- GERHARD-HERMAN M.D., GORNIK H.L., BARRETT C., BARSHES N.R., CORRIERE M.A., DRACHMAN D.E. and LOOKSTEIN R.: 2016 AHA/ACC Guideline on the Management of Patients With Lower Extremity Peripheral Artery Disease: Executive Summary: A Report of the American College of Cardiology/American Heart Association Task Force on Clinical Practice Guidelines. Journal of the American College of Cardiology, 2016.

2- HEO S.H., PARK Y.S., KANG, E.S., PARK, K.B., DO, Y.S., KANG, K.S. and KIM D.I.: Early results of clinical application of autologous whole bone marrow stem cell transplantation for critical limb ischemia with Buerger's disease. Scientific reports, 6, 2016.

3- FRANZ R.W., SHAH K.J., PIN R.H., HANKINS T., HARTMAN J.F. and WRIGHT M.L.: Autologous bone marrow mononuclear cell implantation therapy is an effective limb salvage strategy for patients with severe peripheral arterial disease. Journal of vascular surgery, 62 (3): 673-80, 2015.

4- KLEPANEC A., MISTRIK M., ALTANER C., VALACHOVICOVA M., OLEJAROVA I., SLYSKO R. and TOMKA J.: No difference in intra-arterial and intramuscular delivery of autologous bone marrow cells in patients with advanced critical limb ischemia. Cell transplantation, 21 (9): 1909-18, 2012.
5- MIZUNO H., MIYAMOTO M., SHIMAMOTO M. KOIKE S., HYAKUSOKU H. and KUROYANAGI Y.: Therapeutic angiogenesis by autologous bone marrow cell implantation together with allogeneic cultured dermal substitute for intractable ulcers in critical limb ischaemia J. Plast. Reconstr. Aesthet. Surg., 63: 1875-82, 2010.

6- LAWALL H., BRAMLAGE P. and AMANN B.: Stem cell and progenitor cell therapy in peripheral artery disease. A critical appraisal. [Review]. Thromb. Haemost., 103: 696-709, 2010

7- MADARIC J., KLEPANEC A., VALACHOVICOVA M. MISTRIK M., BUCOVA M., OLEJAROVA I. and VULEV I.: Characteristics of responders to autologous bone marrow cell therapy for no-option critical limb ischemia. Stem Cell Research \& Therapy, 7 (1): 116, 2016.

8- ISMAIL A.M., ABDOU S.M., ATY H.A., KAMHAWY A.H., ELHINEDY M., ELWAGEH M. and SALEM M.L.: Autologous transplantation of CD34+ bone marrow derived mononuclear cells in management of non-reconstructablecritical lower limb ischemia. Cytotechnology, DOI 10.1007/s10616-014-9828-7. Published online 16 December 2014.

9- AMANN B., LUEDEMANN C., RATEI R. and SCHMIDT-LUCKE J.A.: Autologous bone marrow cell transplantation increases leg perfusion and reduces amputations in patients with advanced critical limb ischemia due to peripheral artery disease. Cell transplantation, 18 (3): 371-80, 2009.

10- KIRANA S., STRATMANN B., PRANTE C., PROHASKA W., KOERPERICH H., LAMMERS D. and NANDREAN S.G.: Autologous stem cell therapy in the treatment of limb ischaemia induced chronic tissue ulcers of diabetic foot patients. International Journal of Clinical Practice, 66 (4): 384-93, 2012.

11-De VRIESE A.S., BILLIET J., VAN DROOGENBROECK J., GHEKIERE J. and De LETTER J.A.: Autologous transplantation of bone marrow mononuclear cells for limb ischemia in a caucasian population with atherosclerosis obliterans. Journal of Internal Medicine, 263 (4): 395-403, 2008. 


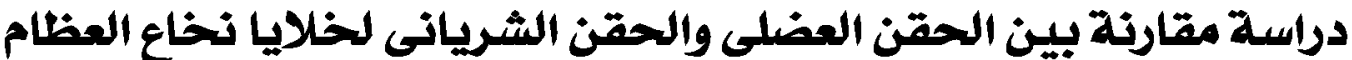

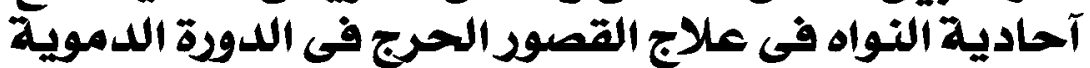

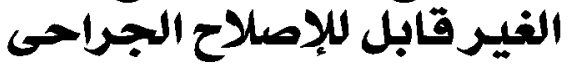

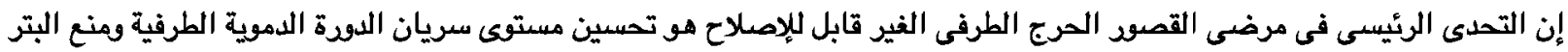

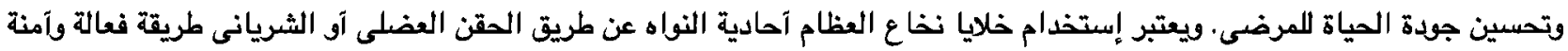

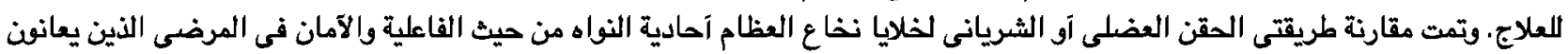

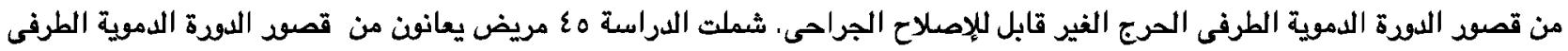

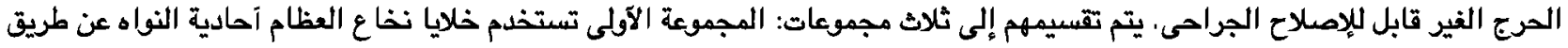

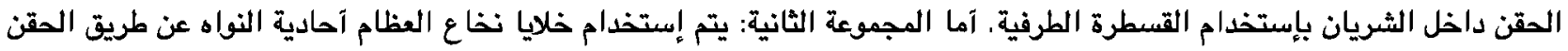

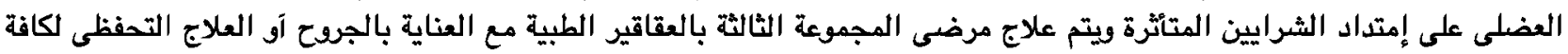
الآعراض.

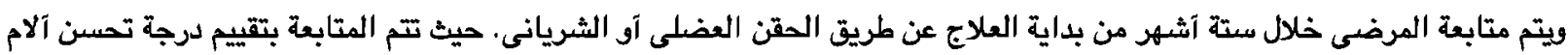

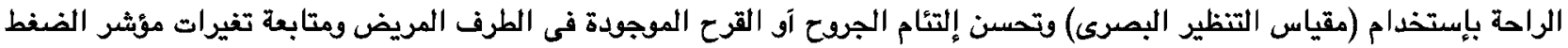

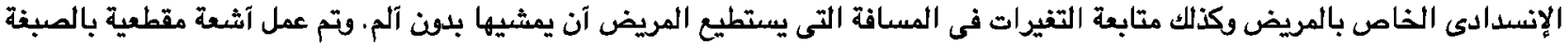

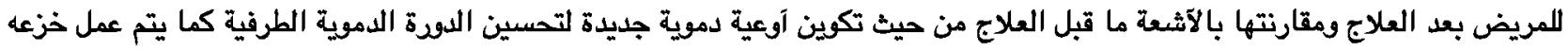

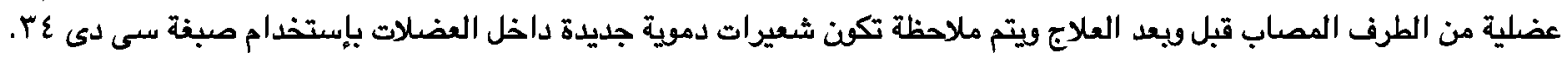

النتائج: فى المجموعتين الآولى والثانية وبعد ستة آشهر من إستخدام الحقن الشريانى آو العضلى للخلايا الجذعية على الترتيب فى 10 التئي

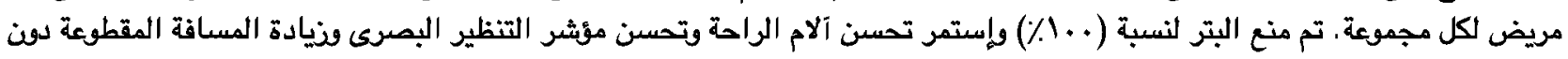

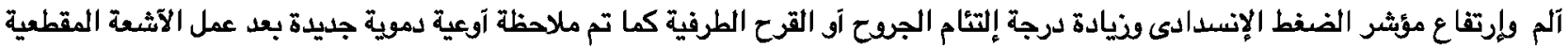

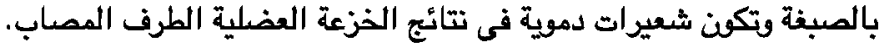

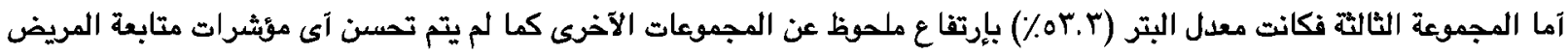

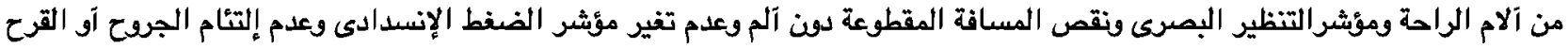

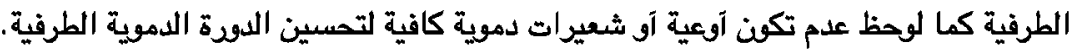

التعليق: شملت طريقة جديدة لعلاج قصود الدوة الدموية الطرفى الحرج الفير قابل للإصلاح الجراحى حيث إن إستخدام الخلايا الجذعية آحادية النواه المشتقة من نخاع العظام طريقة فعالة وآمنة اللعلاج من حيث منع البتر وتحسين جودة العياة العياة للمرضى. 